\title{
Characterization of Strains of Viridans Streptococci by Deoxyribonucleic Acid Hybridization and Physiological Tests
}

\author{
PAMELA P. WELBORN, ${ }^{1 *}$ W. KEITH HADLEY, ${ }^{1}$ ERNEST NEWBRUN,${ }^{2}$ AND DAVID M. YAJKO ${ }^{1}$ \\ Department of Laboratory Medicine, University of California, San Francisco General Hospital, San \\ Francisco, California 94110, ${ }^{1}$ and Division of Oral Biology, Department of Stomatology, University of \\ California, San Francisco, California $94143^{2}$
}

Relationships among selected species of viridans streptococci were studied by using deoxyribonucleic acid (DNA)-DNA hybridization and biochemical and serological tests. The results of hybridization experiments performed with DNA immobilized on membrane filters and index DNA made radioactive with [methyl$\left.{ }^{3} \mathrm{H}\right]$ thymidine indicated that Streptococcus intermedius ATCC $27335^{\text {T }}$ (type strain), Streptococcus constellatus ATCC $27823^{\mathrm{T}}$, Streptococcus mitis ATCC 9895, "Streptococcus MG-intermedius" CDC SS 899, group F strain MGH 8153, and group F strain SFGH 879 are closely related to each other genetically, even though physiological tests indicated that this is a relatively heterogeneous group of organisms. The relative binding ratios for these six strains ranged from 60 to $99 \%$, and the majority of values were greater than $85 \%$, indicating that these strains should be considered members of the same species. Type strain ATCC 33399 (called $S$. mitis) is not a typical $S$. mitis strain based on biochemical test results, and only moderate relatedness $(41 \%)$ was observed in hybridization experiments performed with a typical $S$. mitis strain (strain SS 429). Streptococcus sanguis I ATCC $10556^{\mathrm{T}}$ and $S$. sanguis II ATCC 10557 do not belong in the same species. A low relative binding ratio (13\%) for these strains confirmed similar findings by previous investigators.

The viridans streptococci are the predominant streptococci in the flora of mouths and pharynxes (19). These organisms are the most frequent cause of endocarditis and may be associated with suppurative infections, such as abscesses and empyema $(12,27)$. The first systematic classification of the genus Streptococcus was produced in 1937 by Sherman and included divisions for pyogenic streptococci, enterococci, lactic streptococci, and viridans streptococci (33). Because most of the viridans streptococci do not show group or species specificity with the Lancefield group A, B, C, D, F, and G antisera, species differentiation has been based on other serological methods or physiological test results (12). According to the classification of Sherman, viridans streptococci are not able to cause true beta-hemolysis of blood (33). However, there are beta-hemolytic strains which can exhibit the same serological and physiological characteristics as alpha-hemolytic or nonhemolytic strains that have traditionally been referred to as viridans streptococci (29). There is little agreement in the literature regarding the inclusion of betahemolytic strains in the viridans group $(6,12$, 29).

The physiological characteristics used to iden- tify Streptococcus mutans and Streptococcus salivarius are well established $(2,6,12,13,15$, 29). Identification of strains belonging to these species is facilitated by a number of distinctive physiological characteristics. The classification and nomenclature of the remaining species in the viridans group are confusing due to conflicting reports in the literature.

The Streptococcus sanguis and "Streptococcus mitior" or Streptococcus mitis taxons show considerable overlap in the literature. Colman and Williams (6) described " $S$. mitior" and $S$. sanguis taxons, whereas Facklam preferred to designate " $S$. mitior" strains as $S$. mitis (12). The $S$. sanguis taxon has been divided into $S$. sanguis I and $S$. sanguis II by other investigators (3, 12, 29). Facklam (12) classified most dextran-producing " $S$. mitior" strains as $S$. sanguis II based on acid formation in raffinose broth. According to Facklam, the distinguishing physiological characteristics of $S$. sanguis II strains include formation of acid in lactose, raffinose, and sucrose broths and failure to hydrolyze esculin or form acid in mannitol or inulin broth. S. sanguis I strains are characterized by acid formation in inulin, lactose, and sucrose broths and dextran production on 5\% sucrose 
agar. The distinguishing characteristics of $S$. mitis include formation of acid in lactose and sucrose broths and failure to hydrolyze esculin or form acid in mannitol, inulin, or raffinose broth (12). Some reports have indicated that one well-studied strain, S. sanguis II ATCC 10557, should be considered an aberrant member of $S$. sanguis, if it is included in the taxon at all $(4,9$, 20).

Organisms first described as Streptococcus anginosus by Andrewes and Horder (1) or "Streptococcus milleri" by Guthof (14) have been variously characterized as "Streptococcus MG" (25), minute beta-hemolytic streptococci (23), "Streptococcus MG-intermedius" (12), "Streptococcus anginosus-constellatus" (12), Streptococcus constellatus (16), and "Streptococcus intermedius-MG-anginosus" group (29). Colman and Williams (6) felt that " $S$. MG" and " $S$. milleri" strains were members of the same species and could be identified by their ability to hydrolyze esculin and arginine and their inability to produce acid in mannitol, sorbitol, and inulin broths. Poole and Wilson (28) considered " $S$. MG" (nonhemolytic streptococci belonging to groups $\mathrm{C}, \mathrm{F}$, and $\mathrm{G}$ ) and $S$. anginosus (minute beta-hemolytic streptococci belonging to groups $F$ and $G$ ) the same species and recommended use of the name " $S$. milleri." These authors confirmed earlier reports which indicated that $S$. anginosus is often characterized by Lancefield group $\mathrm{F}$ or $\mathrm{G}$ reactions $(22,26)$. Facklam (12) agreed with the physiological findings of Colman and Williams (6), but separated these organisms into two groups. Lactose-negative strains were designated " $S$. anginosus-constellatus," and lactose-positive strains were designated " $S$. MG-intermedius"' (12). Pulliam et al. (29) considered $S$. anginosus to be more related to " $S$. MG-intermedius" and put these strains together in the " $S$. intermedius-MG-anginosus" group. In a recent study, Ruoff and Kunz (31) stressed the pathogenic role of " $S$. milleri" and identified " $S$. MG-intermedius," " $S$. anginosus-constellatus," and 20 unidentified urine isolates as members of the " $S$. milleri" group.

The difficulties encountered by microbiologists who attempt to identify strains of viridans streptococci result from the conflicting opinions regarding the classification of these organisms. Because most of the taxonomic work involving the viridans streptococci has been based solely upon phenotypic relationships, unreliable estimates of the degrees of relatedness among species may have been accepted.

In this study we included deoxyribonucleic acid (DNA) reassociation data in addition to data from biochemical and serological tests in an effort to clarify the relationships among selected species of viridans streptococci.
(The results were taken from a thesis presented by P.P.W. to the University of California at San Francisco.)

\section{MATERIALS AND METHODS}

Bacterial strains. The following strains were studied: S. constellatus ATCC $27823^{\mathrm{T}}$ (type strain), S, intermedius ATCC $27335^{\mathrm{T}}$, S. mitis ATCC 9895 and ATCC $33399^{\mathrm{T}}$, S. sanguis I ATCC $10556^{\mathrm{T}}$, and $S$. sanguis II ATCC 10557, which were obtained from the American Type Culture Collection, Rockville, Md.; group F strain MGH 8153, which was obtained from L. Kunz, Massachusetts General Hospital, Boston; group F strain SFGH 879 and group G strain SFGH 1235, which were obtained from W. K. Hadley, San Francisco General Hospital, San Francisco, Calif.; and $S$. mitis CDC SS429 and S. MG-intermedius CDC SS899, which were obtained from the Centers for Disease Control, Atlanta, Ga. Four of the strains obtained from the American Type Culture Collection were chosen because they have been designated type strains (34); these were $S$. constellatus ATCC 27823, S. intermedius ATCC 27335, S. sanguis I ATCC $10556^{\mathrm{T}}$, and $S$. mitis ATCC 33399 (= NCTC 3165). Although designated the type strain for $S$. mitis, strain ATCC 33399 was placed in the species $S$. sanguis by Colman and Williams (6) and Cole et al. (5). S. mitis ATCC 9895 was included due to an aberrant esculin hydrolysis reaction, which casts doubt on the correct taxonomic designation of this organism within the viridans group. In addition, this strain has been referred to as "Streptococcus MG" in the literature $(12,17,35,36)$. S. sanguis II ATCC 10557 was of interest because of the controversy surrounding its inclusion in $S$. sanguis; Colman and Williams (6) called this strain " $S$. mitior." A beta-hemolytic group G strain and two minute beta-hemolytic group F strains were chosen to represent beta-hemolytic strains which had biochemical patterns matching those of the " $S$. anginosusconstellatus" group described by Facklam (12). The remaining two strains (" $S$. MG-intermedius" CDC SS899 and S. mitis CDC SS429) are stock strains which yielded typical biochemical reactions, as reported by Facklam (12).

Frozen stock cultures were maintained at $-70^{\circ} \mathrm{C}$ in Trypticase soy broth (BBL Microbiology Systems, Cockeysville, Md.) supplemented with $15 \%$ glycerol. Working cultures were maintained on Trypticase soy agar containing 5\% sheep blood.

Biochemical reactions. A battery of biochemical tests was chosen from the physiological tests studied by Facklam (12) for differentiation of viridans streptococci. Hemolytic action was determined microscopically after anaerobic incubation of 5\% sheep blood-Trypticase soy agar plates inoculated by the streak-stab method (37). Aerobic acid production was tested in heart infusion broth base (Difco Laboratories, Detroit, Mich.) supplemented with bromocresol purple $\mathrm{pH}$ indicator and $1 \%(\mathrm{wt} / \mathrm{vol}$; final concentration) carbohydrate (Difco) (see Table 1). Esculin hydrolysis was determined in basal medium containing $0.03 \%$ esculin ( $\mathrm{K}$ and $\mathrm{K}$ Rare Chemicals) or $0.1 \%$ esculin (11) and no bromocresol purple indicator; 2 drops of $1 \%$ ferric ammonium citrate solution was added after incubation to detect esculin hydrolysis. Production of dextran was tested on heart infusion agar (Difco) supplement- 
ed with $5 \%$ sucrose. The ability to hydrolyze starch was tested on heart infusion agar supplemented with $2 \%$ soluble starch (Difco). Reduction and curd production in litmus milk (Difco) were also determined for each strain.

Two drops of an overnight culture grown in $10 \mathrm{ml}$ of Todd-Hewitt broth (GIBCO Diagnostics, Madison, Wis.) was used as the inoculum for the physiological tests. Plates containing starch and $5 \%$ sucrose were incubated in $5 \% \mathrm{CO}_{2}$ at $35^{\circ} \mathrm{C}$. All broth media were incubated in air at $35^{\circ} \mathrm{C}$. Reactions were read after 24 and $48 \mathrm{~h}$ or after up to 5 days for poorly growing strains.

Serological reactions. All strains were tested for group-specific antigens (groups A through $G$ ) with a Streptex rapid latex test kit (Wellcome Reagents Ltd., Beckenham, England). Extracts were prepared from 24-h cultures grown on Trypticase soy agar containing $5 \%$ sheep blood.

Extraction of DNA. DNA was extracted from cells grown overnight at $37^{\circ} \mathrm{C}$ in a fermentor or on a shaking water bath in 2 liters of Todd-Hewitt broth supplemented with $1 \%$ (wt/vol) $\mathrm{Na}_{2} \mathrm{HPO}_{4}$ (pH 8.0). After autoclaving, filter-sterilized glucose was added to a concentration of $1 \%(\mathrm{wt} / \mathrm{vol})$. Cultures were treated with $10 \mathrm{U}$ of penicillin per $\mathrm{ml}$ of culture for $20 \mathrm{~min}$ before $15 \mathrm{~g}$ of sodium citrate per liter was added and the culture was harvested by centrifugation. The purity of each culture was confirmed by Gram staining and biochemical tests. The harvested cells were washed three times in distilled water and suspended in $25 \mathrm{ml}$ of $0.15 \mathrm{M}$ tris(hydroxymethyl)aminomethane buffer containing $10 \mathrm{mg}$ of lysozyme (7). This was followed by incubation at $37^{\circ} \mathrm{C}$ for 2 to $3 \mathrm{~h}$. The cells were then centrifuged and suspended in $25 \mathrm{ml}$ of $0.1 \mathrm{M} \mathrm{NaCl}-0.1$ $M$ sodium citrate. Lysis was achieved by adding $2 \mathrm{ml}$ of a $25 \%$ sodium lauryl sulfate solution and subsequent heating at $60^{\circ} \mathrm{C}$ for 10 to $30 \mathrm{~min}$. After lysis, $1.25 \mathrm{ml}$ of $5 \%$ pronase (17) was added, and the lysate was incubated overnight at $37^{\circ} \mathrm{C}$. Deproteinization was performed once with $25 \%$ (wt/vol) phenol in standard saline citrate $(1 \times \mathrm{SSC} ; 0.15 \mathrm{M} \mathrm{NaCl}$ plus $0.015 \mathrm{M}$ trisodium citrate) and twice with chloroform-isoamyl alcohol (24:1) before the nucleic acids in the aqueous phase were precipitated with 2 volumes of cold ethanol. The precipitated DNA was dissolved in a minimum amount of $0.01 \times$ SSC and treated with $50 \mu \mathrm{g}$ of ribonuclease I per $\mathrm{ml} \mathrm{(24)}$ and $30 \mu \mathrm{g}$ of ribonuclease $\mathrm{T}_{1}$ per $\mathrm{ml} \mathrm{(32)}$ for $30 \mathrm{~min}$ at $37^{\circ} \mathrm{C}$. The deproteinization steps were then repeated before the final ethanol precipitation step.

The ratio of extinction at $260 \mathrm{~nm}$ to extinction at 230 $\mathrm{nm}$ to extinction at $280 \mathrm{~nm}$ was obtained for each DNA preparation. A ratio which approached or exceeded $1: 0.43: 0.55$ indicated that there was little protein or carbohydrate contamination (24). Isopropanol extraction was performed if required (24). Yield estimates were obtained by comparing the absorbance at $260 \mathrm{~nm}$ of heat-denatured DNA with a standard curve of calf thymus DNA. Samples $(1 \mathrm{ml})$ of DNA in $0.01 \times \mathrm{SSC}$ were stored at $-20^{\circ} \mathrm{C}$ until they were needed for hybridization experiments.

Labeled DNA. Growth of labeled cells was accomplished by adding $1 \mathrm{mCi}$ of $\left[\right.$ methy $\left./{ }^{3} \mathrm{H}\right]$ thymidine to $500 \mathrm{ml}$ of culture medium. The lysis and extraction procedures used were those described above for unlabeled DNA. The specific activities of the labeled
DNAs used in these experiments ranged from 1,200 to $6,500 \mathrm{cpm} / \mu \mathrm{g}$ of DNA.

DNA hybridization. DNAs were hybridized on membrane filters (diameter, $22 \mathrm{~mm}$; type BA85; Schleicher $\&$ Schuell Co., Keene, N.H.) by using the dimethyl sulfoxide method $(10,21)$. Unlabeled DNA $(140$ to 160 $\mu \mathrm{g} / \mathrm{ml}$ ) was denatured by heating at $102^{\circ} \mathrm{C}$ for $15 \mathrm{~min}$ and then rapidly chilled on ice. The DNA concentration was determined spectrophotometrically at 260 nm. A $60-\mu \mathrm{g}$ portion of DNA was applied to each filter, which had been pretreated by soaking in water overnight and rinsing in cold $6 \times$ SSC for $30 \mathrm{~min}$. After prerinsing with $5 \mathrm{ml}$ of ice-cold $6 \times$ SSC (8), the DNA was added with $5 \mathrm{ml}$ of ice-cold $6 \times \mathrm{SSC}$, and the filter was rinsed with an additional $5 \mathrm{ml}$ of ice-cold $6 \times$ SSC (A. L. Coykendall, personal communication). The filters were dried (first at room temperature and then overnight at $60^{\circ} \mathrm{C}$ ) before they were stored in a desiccator at room temperature (18). Blank filters (lacking DNA) were prepared by the same procedure.

Filters containing immobilized DNA were placed in glass liquid scintillation vials containing $1.0 \mathrm{ml}$ of $30 \%$ ( $\mathrm{vol} / \mathrm{vol}$ ) dimethyl sulfoxide in $2 \times \mathrm{SSC}$ for $30 \mathrm{~min}(8)$. Sheared, denatured, ${ }^{3} \mathrm{H}$-labeled index DNA $(0.5 \mu \mathrm{g})$ was added to each scintillation vial. Each reaction was run in triplicate. Negative controls (filters bearing calf thymus DNA) and homologous controls were included with each experiment. Blank filters were used as controls for nonspecific binding of $\left[{ }^{3} \mathrm{H}\right] \mathrm{DNA}$ to the filters. Reassociation of the labeled DNA with the unlabeled, filter-immobilized DNA was allowed to proceed for $16 \mathrm{~h}$ at $48^{\circ} \mathrm{C}$ in a water bath. The temperature was determined from the formula of DeLey and Tijtgat (10). Filters were rinsed at the incubation temperature with $2 \times$ SSC before the hydridized $\left[{ }^{3} \mathrm{H}\right] \mathrm{DNA}$ was quantitated by liquid scintillation counting.

\section{RESULTS}

Physiological characteristics. The results of biochemical and serological tests are shown in Table 1. Each strain was tested with all of the tests a minimum of three times.

The ability to hydrolyze esculin was an aberrant characteristic of $S$. mitis ATCC $33399^{\mathrm{T}}$ and ATCC 9895 based upon the identification scheme proposed by Facklam (12). The production of acid from inulin by $S$. mitis ATCC $33399^{\mathrm{T}}$ was also atypical according to the scheme of Facklam, and S. mitis ATCC 9895 behaved biochemically like " $S$. MG-intermedius". $S$. mitis CDC SS 429 was the only $S$. mitis strain tested which showed typical biochemical characteristics. This strain reacted weakly with the group C antigen in latex agglutination tests; no other $S$. mitis strain demonstrated group A, B, C, D, F, or $\mathrm{G}$ antigen.

The two group $F$ isolates (which produced minute beta-hemolytic colonies on $5 \%$ sheep blood agar) were identical in their carbohydrate reactions to $S$. constellatus ATCC $27823^{\mathrm{T}}$ and the beta-hemolytic group $G$ strain. Except for some variation in the ability to hydrolyze starch, these four isolates reacted identically in the 
TABLE 1. Biochemical and serological reactions of strains used in this study ${ }^{a}$

\begin{tabular}{|c|c|c|c|c|c|c|c|c|}
\hline Strain & Hemolysis & Glucose & Inulin & Lactose & Mannitol & Melibiose & Raffinose & Salicin \\
\hline $\begin{array}{l}S . \text { constellatus } \\
{\text { ATCC } 27828^{\mathrm{T}}}^{\text {AT }}\end{array}$ & $\gamma$ & + & - & - & - & - & - & + \\
\hline $\begin{array}{l}\text { S. intermedius } \\
\text { ATCC } 27335^{\mathrm{T}}\end{array}$ & $\gamma$ & + & - & + & - & - & - & + \\
\hline $\begin{array}{l}\text { S. sanguis I } \\
\text { ATCC } 10556^{T}\end{array}$ & $\alpha$ & + & + & + & - & - & - & $+(w)$ \\
\hline S. mitis ATCC & $\gamma$ & + & + & + & - & - & - & + \\
\hline S. mitis ATCC & $\gamma$ & + & - & + & - & - & - & + \\
\hline $\begin{array}{l}\text { S. sanguis II } \\
\text { ATCC } 10557\end{array}$ & $\alpha$ & + & - & + & - & $\mathbf{v}$ & + & $\mathbf{v}$ \\
\hline $\begin{array}{l}\text { Group F strain } \\
\text { SFGH } 879\end{array}$ & $\beta$ & + & - & - & - & - & - & + \\
\hline $\begin{array}{c}\text { Group F strain } \\
\text { MGH } 8153\end{array}$ & $\boldsymbol{\beta}$ & + & - & - & - & - & - & + \\
\hline $\begin{array}{l}\text { Group G strain } \\
\text { SFGH } 1235\end{array}$ & $\beta$ & + & - & - & - & - & - & + \\
\hline $\begin{array}{l}\text { S. mitis CDC } \\
\text { SS429 }\end{array}$ & $\alpha$ & + & - & + & - & - & - & + \\
\hline $\begin{array}{l}\text { S. MG-inter- } \\
\text { medius CDC } \\
\text { SS899 }\end{array}$ & $\gamma$ & + & - & + & - & - & - & + \\
\hline
\end{tabular}

${ }^{a}$ Abbreviations: +, positive reaction; - , negative reaction; $w$, weak reaction; $v$, variable reaction; $\mathrm{A}$, acid production; C, curd; NA, nonadherent; AD, adherent; NR, no reaction.

${ }^{b}$ Refers to presence of Lancefield group antigen.

remaining biochemical tests. Some variation was also evident in the serological grouping of these strains and in their ability to hemolyze sheep erythrocytes (Table 1). " $S$. MG-intermedius" CDC SS899 was biochemically identical to $S$. intermedius ATCC $27335^{\mathrm{T}}$, although these two strains differed in the serological grouping reaction (Table 1).

The reactions for $S$. sanguis I ATCC $10556^{\mathrm{T}}$ and $S$. sanguis II ATCC 10557 agreed with those reported by Facklam (12).

Hybridizations. The unlabeled DNAs in the homologous reactions bound 36 to $86 \%$ of the total labeled DNAs (mean, $51.2 \% ; n=10$ ), whereas blank filters bound 2.4 to $7.0 \%$ of the labeled DNA (mean, $3.4 \% ; n=10$ ). The relative binding ratios (RBRs) in heterologous reactions (expressed as percentages of homologous binding) remained consistent for most strains even if variation in the extent of homologous binding occurred in subsequent experiments. The mean standard deviation of the RBRs obtained for specific pairings in repeat experiments was $9.6 \%$.

The results of the hybridization experiments (Table 2) are expressed as the mean RBRs obtained in several experiments. High RBRs ( 72 to $93 \%$ ) were obtained with labeled DNA from S. constellatus ATCC $27823^{\mathrm{T}}$ and unlabeled DNAs from $S$. intermedius ATCC $27335^{\mathrm{T}}$, " $S$.
MG-intermedius" CDC SS899, group F strain SFGH 879, group F strain MGH 8153, and $S$. mitis ATCC 9895 . This grouping was confirmed by the results of separate experiments in which labeled DNAs from $S$. intermedius ATCC $27335^{\mathrm{T}}$ and $S$. mitis ATCC 9895 were used. Most of the pairings gave RBRs greater than $70 \%$, although three of the values were slightly lower. Unlabeled DNA from " $S$. MG-intermedius" CDC SS899 hybridized at a very high level (RBR, 104\%) with labeled DNA from $S$. mitis ATCC 9895.

Hybridization experiments in which unlabeled DNAs from the six strains described above and labeled DNAs from $S$. mitis ATCC $33399^{\mathrm{T}}$ and $S$. sanguis II ATCC 10557 were used did not yield any RBR greater than $45 \%$, even though several experiments with $S$. mitis ATCC $33399^{\mathrm{T}}$ DNA resulted in values approaching this figure.

Unlabeled DNA from group G strain SFGH 1235 hybridized at very low levels (RBR, $<25 \%)$ with each labeled index DNA tested.

Low to moderate DNA relatedness values (RBRs, 13 to $47 \%$ ) were obtained in heterologous reactions when unlabeled DNA from $S$. sanguis I ATCC $10556^{\mathrm{T}}$ or $S$. sanguis II ATCC 10557 was incubated with each labeled index DNA.

Unlabeled DNA from $S$. mitis ATCC $33399^{\mathrm{T}}$ produced an RBR of less than $48 \%$ with each 
TABLE 1-Continued

\begin{tabular}{cccccccccc}
\hline Sorbitol & Sucrose & Trehalose & $\begin{array}{c}\text { Litmus } \\
\text { milk }\end{array}$ & $\begin{array}{c}0.03 \% \\
\text { Esculin }\end{array}$ & $\begin{array}{c}0.1 \% \\
\text { Esculin }\end{array}$ & $\begin{array}{c}\text { Starch hy- } \\
\text { drolysis }\end{array}$ & $\begin{array}{c}\text { Arginine } \\
\text { hydrolysis }\end{array}$ & $\begin{array}{c}5 \% \text { Sucrose } \\
\text { agar }\end{array}$ & $\begin{array}{c}\text { Serological } \\
\text { reaction }\end{array}$ \\
\hline- & + & + & A/NR & - & - & - & + & NA & NR \\
- & + & + & A/C & + & + & - & + & NA & G \\
- & + & + & A/C & $\mathbf{v}$ & + & + & + & AD & NR \\
- & + & + & A/NR & + & + & + & + & NA & NR \\
- & + & + & A/C & + & + & w & + & NA & F \\
- & + & - & A/C & - & - & + & - & AD & NR \\
- & + & + & A/NR & - & - & + & + & NA & F \\
- & + & + & A/NR & - & - & + & + & NA & F \\
- & + & + & A/NR & - & - & - & + & NA & G \\
- & + & - & A/C & - & - & - & - & NA & C (w) \\
- & + & + & A/C & + & + & - & + & NA & F (w)
\end{tabular}

labeled index DNA. The highest RBR (47\%) was with labeled DNA from $S$. sanguis II ATCC 10557. S. mitis CDC SS429 gave results comparable to those obtained with $S$. mitis ATCC $33399^{\mathrm{T}}$ in experiments with labeled index DNA.

Unlabeled DNA from $S$. mitis ATCC 9895 yielded low RBRs with labeled DNAs from $S$. mitis ATCC $33399^{\mathrm{T}}$ and S. sanguis II ATCC 10557 (36 and 20\%, respectively). The extent of hybrid formation was greatest with labeled DNAs from $S$. constellatus ATCC $27823^{\mathrm{T}}$ and $S$. intermedius ATCC $27335^{\mathrm{T}}$, as indicated above.

\section{DISCUSSION}

Our results show that six of the strains tested are closely related to each other genetically, even though there is some physiological diversity. Included in this group are $S$. constellatus ATCC $27335^{\mathrm{T}}, S$. mitis ATCC $9895, S$. intermedius ATCC $27335^{\mathrm{T}}$, " $S$. MG-intermedius" CDC SS899, and group F strains SFGH 879 and MGH 8153. The genetic data for these six strains support the findings of Colman and Williams (6), who grouped serologically heterogeneous strains with varying abilities to lyse erythrocytes and ferment lactose into " $S$. milleri." These investigators were not able to separate clearly the minute beta-hemolytic streptococci belonging to groups F and G from " $S$. milleri," and they proposed that these strains be considered varieties of " $S$. milleri". The hybridization results of our study also indicate that minute beta- hemolytic group $\mathrm{F}$ strains should be included in the " $S$. milleri" group. The observations that the minute beta-hemolytic group F strains were lactose negative and that the nonhemolytic group F strain produced acid from lactose were consistent with the findings of Ottens and Winkler (26). These investigators used crossabsorption tests to show that the group antigens of group F streptococci are identical, regardless of the hemolytic ability of the organism. Their results and the genetic data from our study indicate that " $S$. milleri" should include minute beta-hemolytic group $F$ strains and that the division of strains based on ability to produce acid from lactose is not justified.

After the work described in this paper was completed, we learned that strain CDC SS899 (" $S$. MG-intermedius") is identical to $S$. mitis ATCC 9895 (personal communication). This explains the high RBR value obtained when these two strains were used (Table 2) and further supports the grouping of strains ATCC $27823^{\mathrm{T}}$ ( $S$. constellatus), ATCC $27335^{\mathrm{T}}$ ( $S$. intermedius), CDC SS899 ("S. MG-intermedius"), SFGH 879 (group F), MGH 8153 (group F), and ATCC 9895 ( $S$. mitis) into a single species.

Colman and Williams (6) demonstrated that minute beta-hemolytic strains which reacted with Lancefield antisera could be differentiated physiologically from "pyogenes-like" (i.e., large-colony type) strains of the same serological group. In this study we demonstrated that an 
TABLE 2. RBRS

\begin{tabular}{|c|c|c|c|c|c|}
\hline \multirow{2}{*}{ Source of DNA } & \multicolumn{5}{|c|}{ RBR (\%) with ${ }^{3} \mathrm{H}$-labeled DNA from strain: } \\
\hline & ATCC $33399^{\mathrm{T}}$ & ATCC 10557 & ATCC $27823^{\mathrm{T}}$ & ATCC $27335^{\mathrm{T}}$ & ATCC 9895 \\
\hline $\begin{array}{l}\text { S. constellatus } \\
{\text { ATCC } 27823^{\mathrm{T}}}^{\text {ATC }}\end{array}$ & 37 & 21 & 100 & 89 & 75 \\
\hline $\begin{array}{l}\text { S. intermedius } \\
\text { ATCC } 27335^{\mathrm{T}}\end{array}$ & 20 & 20 & 76 & 100 & 64 \\
\hline $\begin{array}{l}\text { "S. MG- } \\
\text { intermedius" } \\
\text { CDC SS899 }\end{array}$ & 45 & 20 & 91 & 99 & 104 \\
\hline $\begin{array}{l}\text { Group F strain } \\
\text { SFGH } 879\end{array}$ & 37 & 16 & 93 & 93 & 59 \\
\hline $\begin{array}{l}\text { Group F strain } \\
\text { MGH } 8153\end{array}$ & 40 & 14 & 72 & 91 & 62 \\
\hline S. mitis ATCC 9895 & 36 & 20 & 81 & 90 & 100 \\
\hline S. mitis CDC SS429 & 41 & 39 & 27 & 40 & 22 \\
\hline $\begin{array}{l}\text { S. mitis ATCC } \\
33399^{\mathrm{T}}\end{array}$ & 100 & 47 & 35 & 37 & 27 \\
\hline S. sanguis I ATCC & 47 & 13 & 18 & 37 & 15 \\
\hline $\begin{array}{l}\text { S. sanguis II ATCC } \\
10557\end{array}$ & 40 & 100 & 22 & 36 & 16 \\
\hline $\begin{array}{l}\text { Group G strain } \\
\text { SFGH } 1235\end{array}$ & 23 & 10 & 21 & 21 & 10 \\
\hline $\begin{array}{l}\text { Calf thymus DNA } \\
\text { (negative control) }\end{array}$ & 1.7 & 0.02 & 1.2 & 1.6 & 3.2 \\
\hline
\end{tabular}

pyogenes-like group $\mathrm{G}$ strain has a low genetic relatedness to " $S$. milleri" strains, some of which possess the group $\mathrm{G}$ antigen, even though the reactions for selected physiological tests were identical. Further hybridization studies with minute beta-hemolytic group $\mathrm{G}$ strains will be required to confirm the suggestion of Colman and Williams (6) that these strains belong in " $S$. milleri."

The inclusion of $S$. mitis ATCC 9895 in " $S$. milleri" based on DNA hybridization results is not surprising in view of references which consider this strain " $S$. MG" $(12,17,35,36)$ and physiological tests which are typical of " $S$. MGintermedius".

Interpretation of the data for the $S$. sanguis and remaining $S$. mitis strains is more difficult and reflects the problems encountered by earlier investigators who studied these organisms. Physiologically, except for glucan production (if this is viewed as a stable characteristic), $S$. mitis ATCC $33399^{\mathrm{T}}$ should be classified as $S$. sanguis I due to acid production in inulin and hydrolysis of esculin. Colman and Williams (6) and Cole et al. (5) included strain ATCC $33399^{\mathrm{T}}$ (= NCTC $3165^{\mathrm{T}}$ ) in $S$. sanguis on the basis of physiological and serological findings. The hybridization experiments performed in this study did not show a high relatedness between $S$. mitis ATCC $33399^{\mathrm{T}}$ and $S$. sanguis I ATCC $10556^{\mathrm{T}}$ or $S$. sanguis II ATCC 10557. These findings support the observations of Cole et al. (5), who put these three strains into three separate groups on the basis of their physiological and serological test results, in addition to their antigenic compositions, as defined by Rosan (30).

The low RBR (13\%) obtained for the heterologous reaction involving $S$. sanguis I ATCC $10556^{\mathrm{T}}$ and $S$. sanguis II ATCC 10557 confirms the data of Coykendall and Specht (9) from DNA hybridization studies involving $S$. sanguis strains. These workers found that these two strains fell into two distinct genetic groups, group 3 ( $S$. sanguis subsp. carlsonii) and group 2 , respectively, and concluded that strains in group 2 should not be considered members of $S$. sanguis. The other genetic group (group $1, S$. sanguis subsp. sanguis) described by Coykendall and Specht includes members which are typically $S$. sanguis. Further studies may show that $S$. mitis ATCC $33399^{\mathrm{T}}$ is a member of group 1. This would explain our results which indicate a moderate degree of relatedness (RBR, 47\%) between strains ATCC $33399^{\mathrm{T}}$ and ATCC $10556^{\mathrm{T}}$.

The physiological characteristics of $S$. mitis CDC SS429 are typical of $S$ mitis strains, but only a moderate degree of relatedness (RBR, 41\%) was observed in the heterologous reaction with labeled DNA from $S$. mitis ATCC $33399^{\mathrm{T}}$. These results indicate that $S$. mitis CDC SS429 and $S$. mitis ATCC $33399^{\mathrm{T}}$ probably do not belong in the same species. Further hybridization studies involving many strains which have 
been identified as $S$. sanguis or $S$. mitis on the basis of physiological characteristics will be required to establish firmly the taxonomic boundaries of these organisms.

DNA hybridization data for the remaining species of viridans streptococci are essential for a thorough characterization of this entire group of organisms.

\section{ACKNOWLEDGMENTS}

We thank C. Hoover (University of California at San Francisco) and B. Byford (San Francisco General Hospital) for providing cultures and preparing media and appreciate the assistance with manuscript preparation provided by $S$. JonesBradley and G. Drummond. The encouragement of A. Coykendall (University of Connecticut Health Center) and his valuable suggestions regarding procedures are gratefully acknowledged.

\section{LITERATURE CITED}

1. Andrewes, F. W., and T. J. Horder. 1906. A study of the streptococci pathogenic for man. Lancet ii:708-713, 775782 , and $852-855$.

2. Carlsson, J. 1967. Presence of various types of nonhemolytic streptococci in dental plaque and in other sites of the oral cavity in man. Odontol. Revy 18:55-74.

3. Carlsson, J. 1968. A numerical taxonomic study of human oral streptococci. Odontol. Revy 19:137-160.

4. Cole, J. S., III, and R. A. Kolstad. 1974. Some atypical features of Streptococcus sanguis ATCC 10557. Int. J. Syst. Bacteriol. 24:370-372.

5. Cole, R. M., G. B. Calandra, E. Huff, and K. M. Nugent. 1976. Attributes of potential utility in differentiating among "group H'" streptococci or Streptococcus sanguis. J. Dent. Res. 55:A142-A153

6. Colman, G., and R. E. O. Williams. 1972. Taxonomy of some human viridans streptococci, p. 281-299. In L. W. Wannamaker and J. M. Matsen (ed.), Streptococci and streptococcal diseases. Academic Press, Inc., New York.

7. Coykendall, A. L. 1970. Base composition of deoxyribonucleic acid isolated from cariogenic streptococci. Arch. Oral Biol. 15:365-368.

8. Coykendall, A. L., F. S. Kaczmarek, and J. Slots. 1980. Genetic heterogeneity in Bacteroides asaccharolyticus (Holdeman and Moore 1970) Finegold and Barnes 1977 (Approved Lists 1980) and proposal of Bacteroides gingivalis sp. nov. and Bacteroides macacae (Slots and Genco) comb. nov. Int. J. Syst. Bacteriol. 30:559-564.

9. Coykendall, A. L., and P. A. Specht. 1975. DNA base sequence homologies among strains of Streptococcus sanguis. J. Gen. Microbiol. 91:92-98.

10. De Ley, J., and R. Tijtgat. 1970. Evaluation of membrane filters for DNA-DNA hybridization. Antonie van Leeuwenhoek J. Microbiol. Serol. 36:461-474.

11. Dowell, V. R., Jr., and T. M. Hawkins. 1977. Laboratory methods in anaerobic bacteriology. Centers for Disease Control, Atlanta, Ga.

12. Facklam, R. R. 1977. Physiological differentiation of viridans streptococci. J. Clin. Microbiol, 5:184-201.

13. Guggenheim, B. 1968 . Streptococci of dental plaques. Caries Res. 2:147-163.

14. Guthof, O. 1956. Pathogenic strains of Streptococcus viridans; streptococci found in dental abscesses and infiltrates in the region of the oral cavity. Zentralbl. Bakteriol. Naturwiss. 166:553-564.

15. Hardie, J. M., and G. H. Bowden. 1976. Physiological classification of oral viridans streptococci. J. Dent. Res. 55:A166-A176.

16. Holdeman, L. V., and W. E. C. Moore. 1974. New genus, Coprococcus, twelve new species, and emended descrip- tions of four previously described species of bacteria from human feces. Int. J. Syst. Bacteriol. 24:260-277.

17. Horsfall, F. L., Jr. 1951. Studies on non-hemolytic streptococci isolated from the respiratory tract of man. The antigenic basis for type specific reactions with Streptococcus salivarius and non-levan-forming streptococci. J. Exp. Med. 93:229-245.

18. Johnson, J. L. 1981. Genetic characterization, p. 450-475. In P. Gerhardt (ed.), Manual of methods for general bacteriology. American Society for Microbiology, Washington, D.C.

19. Jones, D. 1978. Composition and differentiation of the genus Streptococcus, p. 1-40. In F. A. Skinner and L. B. Quensel (ed.), Streptococci. Academic Press, Inc., New York.

20. Lai, C., M. Listgarten, and B. Rosan. 1973. Serology of Streptococcus sanguis: localization of antigens with unlabeled antisera. Infect. Immun. 8:475-481.

21. Legault-Demare, J., B. Desseaux, T. Heyman, S. Seror, and G. P. Ress. 1967. Studies on hybrid molecules of nucleic acids. I. DNA-DNA hybrids on nitrocellulose filters. Biochem. Biophys. Res. Commun. 28:550-557.

22. Liu, P. 1954. Carbon dioxide requirement of group $F$ and minute colony $\mathrm{G}$ hemolytic streptococci. J. Bacteriol. 68:282-288.

23. Long, P. H., and E. A. Bliss. 1934. Studies upon minute hemolytic streptococci. I. The isolation and cultural characteristics of minute beta-hemolytic streptococci. J. Exp. Med. 60:619-631.

24. Marmur, J. 1961. A procedure for the isolation of deoxyribonucleic acid from microorganisms. J. Mol. Biol. 3:208218.

25. Mirick, G., L. Thomas, E. C. Curnen, and F. L. Horsfall, Jr. 1944. Studies on a non-hemolytic streptococcus isolated from the respiratory tract of human beings. J. Exp. Med. 80:391-440.

26. Ottens, H., and K. C. Winkler. 1962. Indifferent and haemolytic streptococci possessing group-antigen F. J. Gen. Microbiol. 28:181-191.

27. Parker, M. T., and L. C. Ball. 1976. Streptococci and aerococci associated with systemic infection in man. J. Med. Microbiol. 9:275-302.

28. Poole, P. M., and G. Wilson. 1976. Infection with minutecolony-forming beta-haemolytic streptococci. J. Clin. Pathol. 29:740-745.

29. Pulliam, L., R. K. Porschen, and W. K. Hadley. 1980. Biochemical properties of $\mathrm{CO}_{2}$-dependent streptococci. J. Clin. Microbiol. 12:27-31.

30. Rosan, B. 1973. Antigens of Streptococcus sanguis. Infect. Immun. 7:205-211.

31. Ruofi, K., and L. J. Kunz. 1982. Identification of viridans streptococci isolated from clinical specimens. J. Clin. Microbiol. 15:920-925.

32. Saito, H., and K. Miura. 1963. Preparation of transforming DNA by phenol treatment. Biochim. Biophys. Acta 72:619-629.

33. Sherman, J. M. 1937. The streptococci. Bacteriol. Rev. 1:3-97.

34. Skerman, V. B. D., V. McGowan, and P. H. A. Sneath (ed.). 1980. Approved lists of bacterial names. Int. J. Syst. Bacteriol. 30:225-420.

35. Weissman, S. M., P. R. Reich, N. L. Somerson, and R. M. Cole. 1966. Genetic differentiation by nucleic acid homology. IV. Relationships among Lancefield groups and serotypes of streptococci. J. Bacteriol. 92:1372-1377.

36. Williamson, C. K. 1964. Serological classification of viridans streptococci from the respiratory tract of man, $p$. 607-622. In C. A. Leone (ed.), International conference on taxonomic biochemistry and serology. The Ronald Press Co., New York.

37. Wilson, G. S., and A. Miles. 1975. The streptococci, p. 712-763. In Principles of bacteriology, virology, and immunity, vol. 1. The Williams \& Wilkins Co., Baltimore. 